\title{
PENGARUH KEPEMIMPINAN TRANSFORMASIONAL, KEMAMPUAN MANAJERIAL, KARAKTERISTIK PEKERJAAN DAN MOTIVASI KERJA TERHADAP KINERJA PEGAWAI DINAS PEMUDA, OLAHRAGA, PARIWISATA DAN KEBUDAYAAN KABUPATEN BARITO SELATAN DI BUNTOK
}

\author{
Sri Demidiyeti \\ Sekolah Tinggi Ilmu Ekonomi Pancasetia Banjarmasin \\ Jl. Ahmad Yani Km. 5.5 Banjarmasin \\ demizee37@gmail.com
}

\begin{abstract}
The purpose of this research was to analized the Effects of Transformational Leadership, Managerial Ability, Job Characteristics, Work Motivation of employee of Sports, Youth, Tourism and Culture Office in Buntok, South Barito Regency. The objects of the study are the employee of the office as many as 67 people. Based on type of research, the writer in conducting the research uses saturation sampling. Data collection techniques using Questioners, Interview and Study Literature Method. Analysis of the data used Multiple Regression Analysis Test.

The result showed : (1) Work Motivation has a dominant influence on Performance of employee of Sports, Youth, Tourism and Culture Office in Buntok, South Barito Regency has proved by the beta coefficient 0,392 most higher value than other variables. (2) Simultaneously Transformational Leadership (X1), Managerial Ability (X2), Job Characteristics (X3), Work Motivation (X4) have a significant effect on the Performance of employee of Sports, Youth, Tourism and Culture Office in Buntok, South Barito Regency.(3) Partially Transformational Leadership (X1), Managerial Ability (X2), Job Characteristics (X3), Work Motivation (X4) have a significant effect on the Performance of employee of Sports, Youth, Tourism and Culture Office in Buntok, South Barito Regency.
\end{abstract}

Keywords : Transformational Leadership, Managerial Ability, Job Characteristics, Work Motivation, performance

Abstrak : Penelitian ini bertujuan untuk menganalisis Pengaruh Kepemimpinan Transformasional, Kemampuan Manajerial, Karakteristik Pekerjaan dan Motivasi Kerja terhadap Kinerja Pegawai Dinas Pemuda, Olahraga, Pariwisata dan Kebudayaan Kabupaten Barito Selatan di Buntok. Obyek penelitian adalah para pegawai Dinas Poraparbud sebanyak 67 pegawai. Penentuan sampel dalam penelitian ini menggunakan sampel jenuh. Teknik pengumpulan data menggunakan kuesioner, wawancara dan metode studi literatur. Analisis data yang digunakan menggunakan analisis regresi linier berganda.

Hasil penelitian menunjukkan bahwa : (1) Motivasi Kerja berpengaruh secara dominan terhadap Kinerja pegawai Dinas Pemuda, Olahraga, Pariwisata dan Kebudayaan Kabupaten Barito Selatan hal ini telah terbukti dengan nilai beta sebesar 0,392 paling besar nilainya dibandingkan dengan nilai beta variable lainnya. (2) Secara simultan Kepemimpinan Transformasional (X1), Kemampuan Manajerial (X2), Karakteristik Pekerjaan (X3), dan Motivasi Kerja (X4) berpengaruh secara signifikan terhadap Kinerja Dinas Pemuda, Olahraga, Pariwisata dan Kebudayaan Kabupaten Barito Selatan. (3) Secara parsial Kepemimpinan Transformasional (X1), Kemampuan Manajerial (X2), Karakteristik Pekerjaan (X3), dan Motivasi Kerja (X4) berpengaruh secara signifikan terhadap Kinerja Dinas Pemuda, Olahraga, Pariwisata dan Kebudayaan Kabupaten Barito Selatan.

Kata Kunci : Kepemimpinan transformasional, Kemampuan Manajerial, Karakteristik Pekerjaan, Motivasi Kerja, Kinerja Pegawai 


\subsection{Latar Belakang Masalah}

Di dalam setiap instansi, tak akan terlepas dari adanya sumber daya manusia. Pengakuan akan pentingnya sumber daya manusia dalam setiap instansi merupakan salah satu faktor yang vital bagi pencapaian tujuan instansi dan pemanfaatan berbagai fungsi di dalam kegiatan manajemen agar efektif dan efisien. Untuk itu mengelola sumber daya manusia senantiasa perlu mengadakan integrasi antara kebutuhan, sifat, dan perilaku individu dengan kebutuhan dan keinginan instansi.

\section{Pentingnya}

untuk melasanakan misi dan mencapai visi dinas adalah melalui aspek operasional dan setiap pegawai dituntut untuk dapat menciptakan, memperoleh, menginterpretasikan, mentrasfer dan membagi pengetahuan, yang bertujuan untuk merubah perilakunya dan bersedia mengaplikasikan dalam setiap pekerjaan (Garvin, 2000 : 11). Pada dinas Poraparbud demi tercapainya tujuan visi dan misi yang baik, diharapkan dapat melakukan kerjasama dengan pihak yang terkait sebagai media untuk kesuksesan visi dan misi Disporaparbud.

Tidak optimalnya kinerja yang dilakukan oleh para pegawai mengakibatkan tugas utama Disporaparbud tidak tercapai dengan sempurna, hal ini akan menurunkan kualitas pengelolaan fungsi, sehingga tata kelola Disporaparbud yang baik tidak terlaksana. Untuk kegiatan kegiatan bidang masih banyak melibatkan bidang lain sehingga tupoksi tambahan yang diberikan kadang - kadang membuat tidak maksimal nya kinerja sumber daya manusia nya. Sebagai contoh untuk tahun 2019 hampir setiap event bidang budaya selalu melibatkan bidang lain. Pada Surat Keputusan Bupati Barito Selatan untuk Pembentukan Panitia Festival Seni Budaya Pelajar Sekolah Lanjutan Tingkat Atas se Kalimantan Tengah Tahun 2019 Nomor : 188.45/327/2019, dapat di lihat melibatkan bidang Pariwisata, bidang sekretariat serta tenaga tenaga kontrak dari semua bidang. Berdasarkan latar belakang masalah yang telah diuaraikan, maka perlu dikaji variabel-variabel yang berhubungan kinerja pegawai yaitu ; kepemimpinan transformasional, kemampuan manajerial, karakteristik pekerjaan, dan motivasi kerja, menarik untuk dilakukan penelitian sehingga akan memberikan gambaran yang jelas tentang permasalahan yang dihadapi Disporaparbud.

\subsection{Perumusan Masalah}

Berdasarkan penjelasan tersebut maka pertanyaan penelitian yang akan diajukan untuk penelitian ini adalah :

1. Apakah variabel Kepemimpinan

Transformasional, Kemampuan Manajerial, Karakteristik Pekerjaan dan Motivasi Kerja berpengaruh secara simultan terhadap Kinerja Pegawai dinas Poraparbud Kabupaten Barito Selatan di Buntok?

2. Apakah variabel Kepemimpinan Transformasional, Kemampuan Manajerial, Karakteristik Pekerjaan dan Motivasi Kerja berpengaruh secara parsial 
86 Kindai, Vol 17, Nomor 1, Halaman 084 - 099

terhadap Kinerja Pegawai dinas

Poraparbud Kabupaten Barito

Selatan di Buntok?

3. Variabel manakah yang lebih dominan mempengaruhi

Kinerja Pegawai dinas

Poraparbud Kabupaten Barito

Selatan di Buntok?

\subsection{Tujuan Penelitian}

Berdasarkan rumusan di atas, maka tujuan penelitian ini adalah sebagai berikut.

1. Untuk mengetahui dan menganalisis Kepemimpinan Transformasional, Kemampuan Manajerial, Karakteristik Pekerjaan dan Motivasi Kerja berpengaruh secara simultan terhadap Kinerja Pegawai dinas Poraparbud Kabupaten Barito Selatan di Buntok.

2. Untuk mengetahui dan menganalisis Kepemimpinan Transformasional,

Kemampuan Manajerial, Karakteristik Pekerjaan dan Motivasi Kerja berpengaruh secara parsial terhadap Kinerja Pegawai dinas Poraparbud Kabupaten Barito Selatan di Buntok.

3. Untuk mengetahui dan menganalisis diantara variabel Kepemimpinan

Transformasional, Kemampuan Manajerial, Karakteristik Pekerjaan dan Motivasi Kerja yang paling dominan mempengaruhi Kinerja Pegawai dinas Poraparbud Kabupaten Barito Selatan di Buntok.

\subsection{Kegunaan Penelitian}

Berikut ini akan dijelaskan mengenai manfaat yang diharapkan dapat diperoleh dari penelitian ini. Adapun manfaat tersebut meliputi :
1. Aspek Akademis

a. Untuk memperdalam wawasan dan implementasi secara operasional di bidang manajemen sumber daya manusia khususnya mengenai tentang Kepemimpinan Transformasional, Kemampuan Manajerial, Karakteristik Pekerjaan dan Motivasi Kerja dan Kinerja.

b. Sebagai referensi guna penelitian lebih lanjut khususnya berkaitan dengan peningkatan Kinerja.

2. Aspek Pengembangan Ilmu Pengetahuan

Memberikan sumbangan pikiran bagi konseptual terhadap ilmu pengetahuan agar dapat lebih cepat menyesuaikan dengan perkembangan ilmu bidang pengetahuan yang lain sebagai upaya untuk mengikuti perubahan dan pengambilan kebijaksanaan yang berkaitan dengan Kepemimpinan

Transformasional,

Kemampuan Manajerial, Karakteristik Pekerjaan dan Motivasi Kerja dan Kinerja.

3. Aspek Praktis

a. Sebagai bahan informasi bagi pihak-pihak pengambil kebijakan dan keputusan di instansi Dinas DiporaparbudKabupaten Barito Selatan dan bagi pihak lain yang 
berkepentingan dengan usaha pengembangan di bidang manajemen sumber daya manusia.

b. Sebagai bahan masukan untuk pertimbangan perubahan yang ada dalam internal organisasi Dinas Poraparbud Kabupaten Barito Selatan.

\subsection{Landasan Teori}

\subsubsection{Kepemimpinan} Transformasional

Northouse

(2013:175)

mendefenisikan

kepemimpinan

transformasional sebagai proses yang mengubah orang-orang. Hal itu peduli dengan emosi, nilai, etika, standar dan tujuan jangka panjang serta menyangkut penilaian pada motif pengikut, memuaskan kebutuhan mereka, dan memperlakukan mereka sebagai manusia secara utuh.

\subsubsection{Kemampuan Manajerial}

Para pengelola atau penanggung jawab organisasi untuk dapat melaksanakan tugas dan kewajibannya dengan baik dapat mengandalkan kemampuan atau keahlian konseptual, keahlian hubungan antar manusia, keahlian teknikal dan keahlian pengambilan keputusan (Jeff Madura, 2001 : 230). Keahlian-keahlian tersebut akan menjadi kemampuan manajerial dalam mengembangakan dan mengendalikan organisasi, karena keberhasilan pimpinan organisasi tergantung pada kemampuan manajerialnya. Jabatan yang lebih rendah dibutuhkan ketrampilan teknis yang lebih banyak dan sedikit menggunakan kemampuan manajerialnya.

Kemampuan manajerial adalah kemampuan untuk memahami dan mengimplementasikan fungsi-fungsi manajemen dalam organisasi sesuai dengan lingkungan organisasi (Handoko, 1990:23) Makin tinggi jenjang jabatannya maka akan semakin dituntut untuk meningkatkan kemampuan manajerialnya. Prinsip dari manajerial adalah penguasaan inti dari manajemen yang terdiri dari:

1). Fungsi perencanaan (Planning), 2). Pengorganisasian (Organizing),
3). Penyusunan (Staffing),
4). Pengarahan (Directing),
5).
Pengawasan (Controlling).

\subsubsection{Karakteristik Pekerjaan}

Suatu pekerjaan dapat memotivasi atau tidak, tergantung dari bagaimana pekerjaan dirancang, apakah pekerjaan itu dapat menyediakan lebih banyak atau lebih sedikit kesempatan bagi tenaga kerja untuk memuaskan kebutuhan mereka yang berhubungan dengan pekerjaan. Suatu pekerjaan yang memberikan ruang gerak yang lebih luas dapat memuaskan kebutuhan seseorang untuk rnenjadi kreatif. Oleh sebab itu manajer dan pekerja bersama-sarna menemukan bahwa karakteristik pekerjaan memerlukan perspektif yang lebih luas dari pada yang telah dilakukan di masa lalu.

Mangkuprawira (2007) menyatakan bahwa; karakteristik pekerjaan adalah identifikasi beragam dimensi pekerjaan yang secara simultan memperbaiki efisiensi organisasi dan kepuasan kerja. Menurut Schermerhom (2007) bahwa; karakteristik pekerjaan merupakan atribut atribut tugas yang memiliki sifat penting khusus. Suatu pekerjaan yang memiliki karakteristik yang menarik bagi karyawan dan menyenangkan untuk dikerjakan dapat menimbulkan motivasi bagi karyawan tersebut. Suatu pekerjaan juga dapat didesain sedemikian rupa supaya dapat memberi motivasi, menghasilkan 
88 Kindai, Vol 17, Nomor 1, Halaman 084 - 099

kepuasan kerja dan produktif bagi karyawan yang mengerjakanna (Sedarmayanti, 2008). Karakteristik pekerjaan juga dikenal sebagai elemen perilaku.

Ada empat elemen perilaku yang sangat mempengaruhi kualitas kehidupan kerja dan tercermin pada kepuasan individu para pemegang jabatan yaitu otonomi, variasi, identitas tugas dan umpan balik (Handoko,2006).

\subsubsection{Motivasi Kerja}

Menurut Luthans (2006)

motivasi adalah proses sebagai langkah awal seseorang melakukan tindakan akibat kekurangan secara fisik dan psikis atau dengan kata lain adalah suatu dorongan yang ditunjukan untuk memenuhi tujuan tertentu. Motivasi merupakan dorongan pada diri seseorang untuk melakukan sesuatu agar dapat mencapai kebutuhan dirinya. Motivasi terpengaruh karena lingkungan yang selalu berada disekitarnya dapat menimbulkan motivasi pada dirinya.

Menurut Maslow (Robbins, 2001:167), hierarki kebutuhan manusia merupakan prediksi dan deskripsi dari motivasi.. Maslow mendasarkan teorinya ini pada dua asumsi, yaitu:

1) Kebutuhan manusia bergantung pada apa yang telah ia punyai. Kebutuhan yang belum terpenuhi akan dapat mempengaruhi tingkah laku, tetapi kebutuhan-kebutuhan yang telah terpuaskan tidak akan bergerak sebagai motivator.

2) Kebutuhan-kebutuhan disusun dalam suatu hierarki kepentingan. Bila suatu kebutuhan telah dapat dipenuhi, kebutuhan yang lain akan muncul dan menuntut kepuasan.

Dari titik pandang motivasi teori ini mengatakan bahwa meskipun tidak ada kebutuhan yang pernah dipenuhi secara lengkap, suatu kebutuhan yang dipuaskan secara cukup banyak (substantial) tidak lagi memotivasi. Jadi menurut Maslow, jika ingin memotivasi seseorang harus memahami sedang pada tingkatan mana kebutuhan orang itu dan memfokuskan pada pemenuhan kebutuhan-kebutuhan itu.

\subsubsection{Kinerja}

Kinerja didefinisikan oleh Prawirosentono (2005: 21) adalah hasil kerja yang dapat dicapai oleh seseorang atau sekelompok orang dalam suatu organisasi sesuai dengan wewenang dan tangung jawab masing-masing, dalam rangka upaya mencapai tujuan organisai bersangkutan secara legal, tidak melanggar hukum dan sesuai dengan moral dan etika. Mangkunegara menyatakan (2005: 17) adalah hasil kerja secara kualitas dan kuantitas yang dicapai oleh seorang pegawai dalam melaksanakan tugasnya sesuai dengan tanggung jawab yang diberikan kepadanya. Selain itu, kinerja juga dapat diartikan sebagai suatu hasil dan usaha seseorang yang dicapai dengan adanya kemampuan dan perbuatan dalam situasi tertentu.

\subsection{Kerangka Konseptual}

Berdasarkan pada faktor-faktor yang memiliki pengaruh Kepemimpinan transformasional, Kemampuan Manajerial, Karakterisik Pekerjaan, dan Motivasi terhadap Kinerja Pegawai Dinas Pemuda, Olahraga, Pariwisata dan Kebudayaan Kabupaten Barito Selatan di Buntok maka paradigma penelitian ini ditunjukkan oleh gambar berikut: 


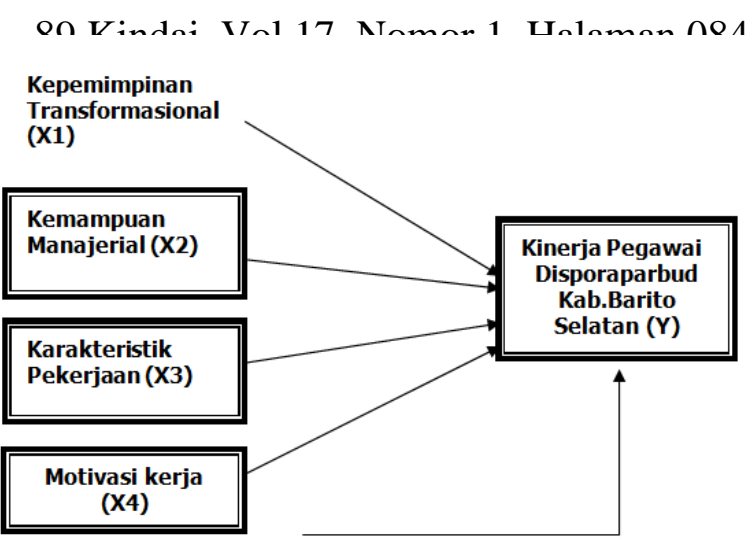

Gambar 3.1

Kerangka Konseptual Penelitian

(Sumber : Hasil Diolah Peneliti 2020)

\subsection{Hipotesis}

Berdasarkan kerangka proses berpikir dan kerangka konseptual penelitian maka hipotesis dalam penelitian ini dapat dirumuskan sebagai berikut :

1. Variabel

Kepemimpinan

Transformasional (X1), Kemampuan Manajerial (X2), Karakteristik Pekerjaan (X3) dan Motivasi Kerja (X4) berpengaruh secara simultan terhadap Kinerja Pegawai Disporaparbud Kabupaten Barito Selatan di Buntok.

2. Variabel

Kepemimpinan

Transformasional (X1), Kemampuan Manajerial (X2), Karakteristik Pekerjaan (X3) dan Motivasi Kerja (X4) berpengaruh secara parsial terhadap Kinerja Pegawai Disporaparbud Kabupaten Barito Selatan di Buntok.

3. Variabel Motivasi Kerja memiliki pengaruh secara dominan terhadap Kinerja Pegawai Disporaparbud Kabupaten Barito Selatan di Buntok.

\subsection{Populasi dan Sampel}

Populasi dalam penelitian ini adalah semua pegawai yang masih aktif bekerja di kantor dinas Poraparbud Kabupaten Barito Selatan. Jumlah pegawai sebagai populasi yang terdiri dari pegawai negeri sipil sebanyak 37 pegawai dan non pegawai negeri sipil sebanyak 30 yang masih aktif bekerja, total populasi sebanyak 67 pegawai.

Penentuan sampel dalam penelitian ini menggunakan sampel jenuh atau sensus karena jumlah populasi sudah mencukupi sebagai sampel (Soegiono, 2004). Dalam penelitian yang menggunakan sampel jenuh tidak ada toleransi kesalahan atau penyimpangan karena semua populasi dijadikan sampel, artinya probabilitas kesalahan tidak ada.

\subsection{Teknik Pengumpulan Data}

Teknik pengumpulan data dalam penelitian ini antara lain:

1. Metode kuesioner, suatu cara untuk mendapatkan data dengan menyebarkan kuesioner yang telah disusun oleh peneliti sesuai dengan tujuan. Jenis pertanyaan atau pernyataan yang digunakan adalah jenis pertanyaan/pernyataan tertutup dengan lima alternatif pilihan, yaitu untuk data mengenai variabel Kepemimpinan Transformasional, Kemampuan Manajerial, Karakteristik Pekerjaan, Motivasi Kerja dan Kinerja.

2. Metode wawancara, yaitu mengadakan tanya jawab dengan responden maupun pihak-pihak yang terkait dalam hal pendapat responden mengenai variabel Kepemimpinan Transformasional, Kemampuan Manajerial, Karakteristik Pekerjaan, Motivasi Kerja dan Kinerja

3. Metode Studi Literatur, yaitu mempelajari literatur atau acuan yang ada, baik literatur yang bersifat teoritis maupun literatur dan data yang ada di instansi sebagai obyek yang diteliti. Tinjauan teori diambil dari literatur untuk menjadi dasar penyusunan kerangka konseptual dan hipotesis, 
90 Kindai, Vol 17, Nomor 1, Halaman 084 - 099

yang berkaitan dengan masalah variabel Kepemimpinan

Transformasional, Kemampuan Manajerial, Karakteristik Pekerjaan, Motivasi Kerja dan Kinerja.

\subsection{Pengujian Hipotesis}

Berdasarkan basil perhitungan dengan menggunakan program SPSS, maka dapat digunakan sebagai dasar dalam menganalisis untuk membuktikan hipotesis yang diajukan. Pembuktian hipotesis yang diajukan dapat menggunakan uji statistik yang didukung oleh uji ekonometrika dengan cara sebagai berikut:

\section{Pengujian Hipotesis, uji}

simultan.

\section{Pengujian Hipotesis, uji parsial.}

3. Pengujian Hipotesis, uji dominan

\subsection{Analisis Hasil Penelitian}

\subsubsection{Uji Validitas}

Uji validitas merupakan cara untuk menguji apakah instrumen yang dipergunakan dalam penelitian layak dipergunakan dan mampu menghasilkan data yang akurat sesuai dengan tujuan pengukurannya. Intrumen yang valid berarti alat ukur yang digunakan untuk mendapatkan data (mengukur) itu valid.

Berikut ini hasil pengujian uji validitas :

Tabel 5.31

Hasil Uji Validitas Instrumen Kepemimpinan Transformasional (X1)

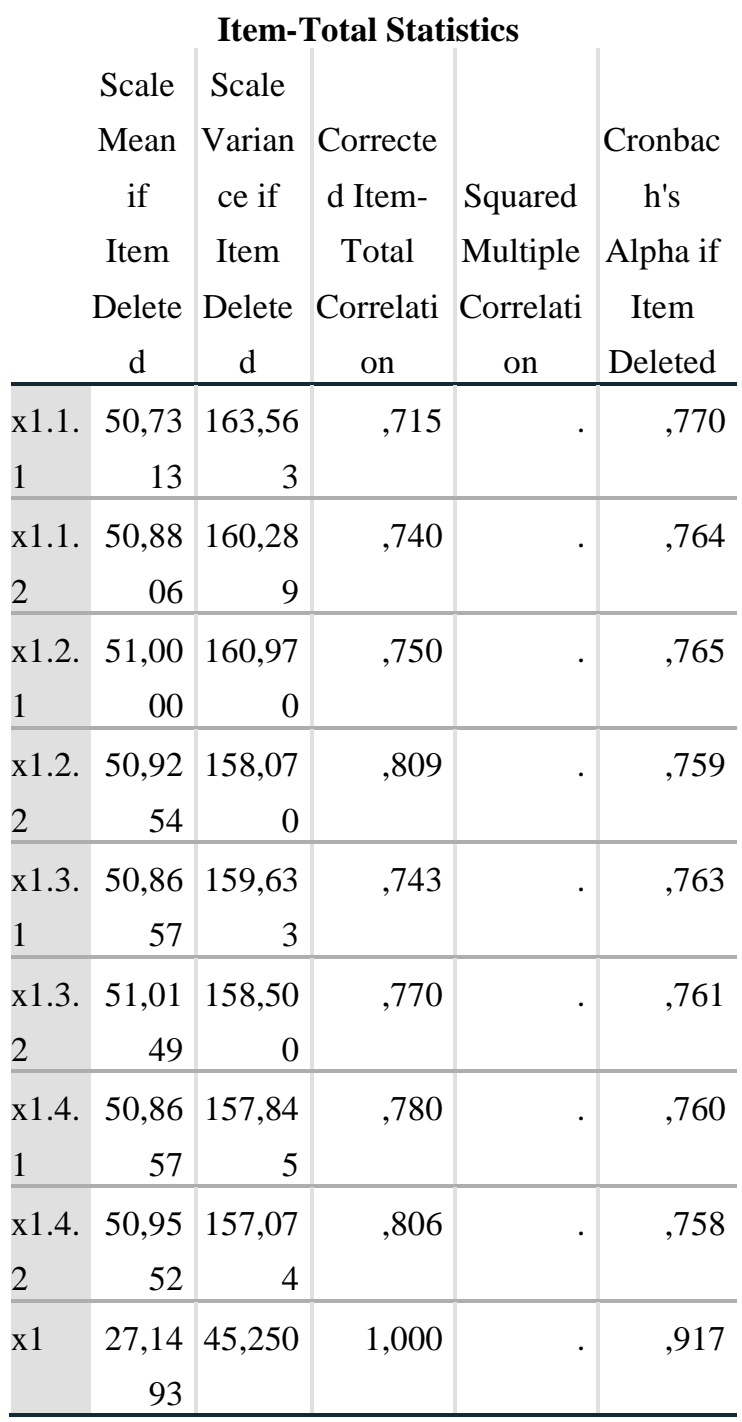

Sumber : Print Out spss

Berdasarkan Tabel 5.31 dari hasil perhitungan statistik diperoleh nilai $r$ hitung dalam kolom Corrected Item-Total Correlation variabel Kepemimpinan Transformasional lebih besar dari $\mathrm{r}$ tabel sebesar 0,246 sehingga dapat dinyatakan bahwa semua item instrumen untuk variabel Kepemimpinan Transformasional adalah valid (Ghozali, 2004:137). Artinya apabila instrumen yang digunakan dalam mencari data adalah valid maka data yang diperoleh untuk penelitian juga pasti valid. 
Tabel 5.32

Hasil Uji Validitas Instrumen

Kemampuan Manajerial (X2)

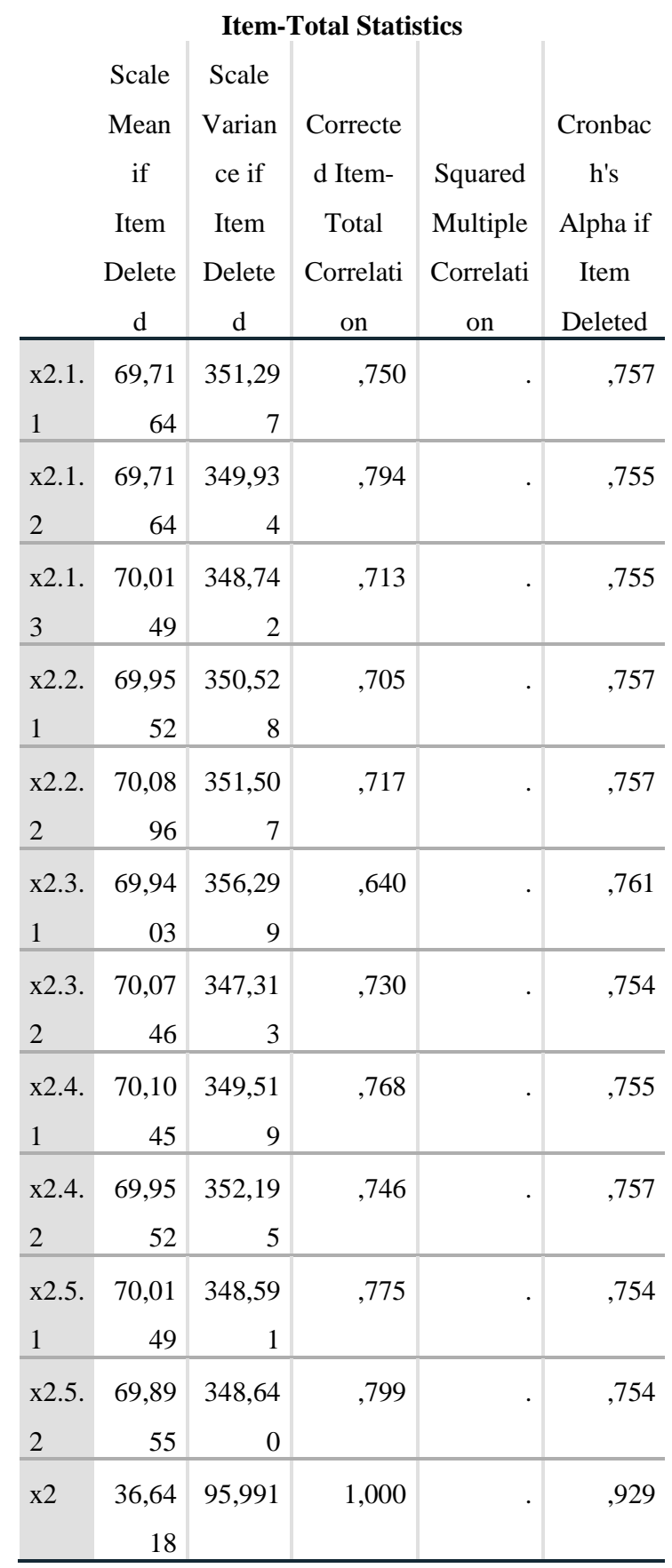

Sumber : Print out spss

Berdasarkan Tabel 5.32 dari hasil perhitungan statistik diperoleh nilai $r$ hitung dalam kolom Corrected Item-Total Correlation Kemampuan Manajerial lebih besar dari $r$ tabel sebesar 0,246 sehingga dapat dinyatakan bahwa semua item instrumen untuk variabel
Kemampuan Manajerial adalah valid (Ghozali, 2004:137). Artinya apabila instrumen yang digunakan dalam mencari data adalah valid maka data yang diperoleh untuk penelitin pasti juga valid.

Tabel 5.33

Hasil Uji Validitas Instrumen Karakteristik Pekerjaan (X3)

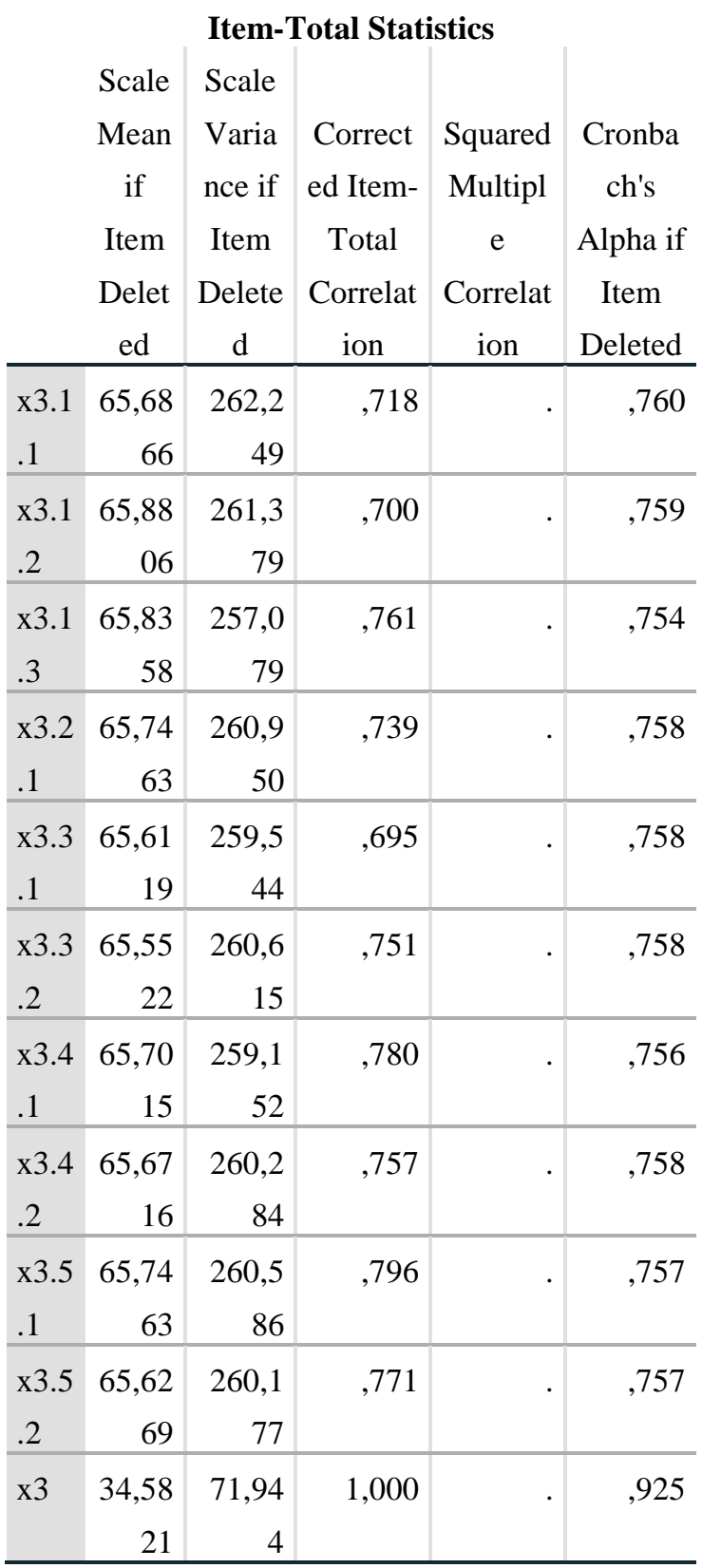

Sumber : Print Out SPSS

Berdasarkan Tabel 5.33 dari hasil perhitungan statistik diperoleh nilai $r$ hitung dalam kolom Corrected Item-Total Correlation Karakteristik Pekerjaan lebih 
92 Kindai, Vol 17, Nomor 1, Halaman 084 - 099

besar dari $r$ tabel sebesar 0,246 sehingga dapat dinyatakan bahwa semua item instrumen untuk variabel Karakteritik Pekerjaan adalah valid (Ghozali, 2004:137). Artinya apabila instrumen yang digunakan dalam mencari data adalah valid maka data yang diperoleh untuk penelitian pasti juga valid.

Tabel 5.34

Hasil Uji Validitas Instrumen Motivasi Kerja (X4)

\begin{tabular}{|c|c|c|c|c|c|}
\hline \multicolumn{6}{|c|}{ Item-Total Statistics } \\
\hline & $\begin{array}{l}\text { Scale } \\
\text { Mean } \\
\text { if } \\
\text { Item } \\
\text { Delet } \\
\text { ed }\end{array}$ & $\begin{array}{c}\text { Scale } \\
\text { Varia } \\
\text { nce if } \\
\text { Item } \\
\text { Delete } \\
\text { d }\end{array}$ & $\begin{array}{c}\text { Correct } \\
\text { ed } \\
\text { Item- } \\
\text { Total } \\
\text { Correlat } \\
\text { ion }\end{array}$ & $\begin{array}{c}\text { Squared } \\
\text { Multipl } \\
\mathrm{e} \\
\text { Correlat } \\
\text { ion }\end{array}$ & $\begin{array}{c}\text { Cronba } \\
\text { ch's } \\
\text { Alpha } \\
\text { if Item } \\
\text { Deleted }\end{array}$ \\
\hline $\begin{array}{l}\mathrm{X} 4 . \\
1.1\end{array}$ & $\begin{array}{r}83,94 \\
03 \\
\end{array}$ & $\begin{array}{r}415,4 \\
51 \\
\end{array}$ &, 721 & & ,758 \\
\hline $\begin{array}{l}\mathrm{X} 4 . \\
1.2\end{array}$ & $\begin{array}{r}84,02 \\
99 \\
\end{array}$ & $\begin{array}{r}414,8 \\
78 \\
\end{array}$ & 677 & & ,758 \\
\hline $\begin{array}{l}X 4 . \\
2.1\end{array}$ & $\begin{array}{r}83,95 \\
52\end{array}$ & $\begin{array}{r}417,2 \\
86\end{array}$ & ,678 & & ,759 \\
\hline $\begin{array}{l}\mathrm{X} 4 . \\
2.2\end{array}$ & $\begin{array}{r}83,82 \\
09\end{array}$ & $\begin{array}{r}414,0 \\
28 \\
\end{array}$ & ,729 & . & ,757 \\
\hline $\begin{array}{l}\mathrm{X} 4 . \\
3.1\end{array}$ & $\begin{array}{r}83,86 \\
57 \\
\end{array}$ & $\begin{array}{r}406,0 \\
88 \\
\end{array}$ &, 824 & & ,751 \\
\hline $\begin{array}{l}\mathrm{X} 4 . \\
3.2\end{array}$ & $\begin{array}{r}84,00 \\
00\end{array}$ & $\begin{array}{r}409,2 \\
12 \\
\end{array}$ &, 750 & & ,754 \\
\hline $\begin{array}{l}\mathrm{X} 4 . \\
4.1\end{array}$ & $\begin{array}{r}83,80 \\
60 \\
\end{array}$ & $\begin{array}{r}408,4 \\
62\end{array}$ & ,808 & & ,753 \\
\hline $\begin{array}{l}\mathrm{X} 4 . \\
4.2\end{array}$ & $\begin{array}{r}83,86 \\
57 \\
\end{array}$ & $\begin{array}{r}412,4 \\
21 \\
\end{array}$ &, 790 & . & ,755 \\
\hline $\begin{array}{l}\mathrm{X} 4 . \\
5.1\end{array}$ & $\begin{array}{r}84,04 \\
48 \\
\end{array}$ & $\begin{array}{r}410,6 \\
80 \\
\end{array}$ & ,778 & . & ,754 \\
\hline $\begin{array}{l}\mathrm{X} 4 . \\
5.2\end{array}$ & $\begin{array}{r}83,85 \\
07 \\
\end{array}$ & $\begin{array}{r}413,1 \\
29\end{array}$ &, 755 & & ,756 \\
\hline $\begin{array}{l}\mathrm{X} 4 . \\
6.1\end{array}$ & $\begin{array}{r}83,83 \\
58 \\
\end{array}$ & $\begin{array}{r}415,1 \\
70\end{array}$ & 692 & . & ,758 \\
\hline $\begin{array}{l}X 4 . \\
6.2\end{array}$ & $\begin{array}{r}83,83 \\
58 \\
\end{array}$ & $\begin{array}{r}413,5 \\
33 \\
\end{array}$ & ,711 & . & ,757 \\
\hline $\mathrm{x} 4$ & $\begin{array}{r}43,77 \\
61\end{array}$ & $\begin{array}{r}112,1 \\
46\end{array}$ & 1,000 & & ,936 \\
\hline
\end{tabular}

\section{Sumber : Print Out SPSS}

Berdasarkan Tabel 5.34 dari hasil perhitungan statistik diperoleh nilai $r$ hitung dalam kolom Corrected Item-Total Correlation Motivasi lebih besar dari $\mathrm{r}$ tabel sebesar 0,246 sehingga dapat dinyatakan bahwa semua item instrumen untuk variabel Motivasi adalah valid (Ghozali, 2004:137). Artinya apabila instrumen yang digunakan dalam mencari data adalah valid maka data yang diperoleh untuk penelitian pasti juga valid.

Tabel 5.35

Hasil Uji Validitas Instrumen Kinerja (Y)

\section{Item-Total Statistics}

\begin{tabular}{c|c|c|c|c} 
Scale & Scale & & & \\
Mean & Varia & Correcte & & Cronba \\
if & nce if & d Item- & Squared & ch's \\
Item & Item & Total & Multiple & Alpha if \\
Delet & Delete & Correlat & Correlat & Item
\end{tabular}

\begin{tabular}{|c|c|c|c|c|c|}
\hline & ed & d & ion & ion & Deleted \\
\hline у.1 & 60,01 & 164,5 & 667, & & 768 \\
\hline .1 & 49 & 91 & & & \\
\hline у. 1 & 59,82 & 163,1 & ,735 & & ,765 \\
\hline .2 & 09 & 49 & & & \\
\hline y. 2 & 59,89 & 160,5 & ,781 & & ,760 \\
\hline .1 & 55 & 80 & & & \\
\hline y.2 & 59,82 & 161,0 & ,751 & & ,761 \\
\hline .2 & 09 & 28 & & & \\
\hline y.3 & 60,01 & 159,3 & ,775 & & 758 \\
\hline .1 & 49 & 48 & & & \\
\hline y.3 & 59,95 & 160,0 & ,788 & & 759 \\
\hline .2 & 52 & 74 & & & \\
\hline у.4 & 60,13 & 160,0 & ,731 & & 760 \\
\hline .1 & 43 & 27 & & & \\
\hline y.4 & 59,89 & 159,9 & ,782 & & ,759 \\
\hline .2 & 55 & 74 & & & \\
\hline $\mathrm{Y}$ & 31,97 & 45,69 & 1,000 & & 911 \\
\hline & 01 & 6 & & & \\
\hline
\end{tabular}

Sumber : Print Out SPSS 
Berdasarkan Tabel 5.35 dari hasil perhitungan statistik diperoleh nilai $r$ hitung dalam kolom Corrected Item-Total Correlation Kinerja pegawai lebih besar dari $r$ tabel sebesar 0,246 sehingga dapat dinyatakan bahwa semua item instrumen untuk variabel Kinerja pegawai adalah valid (Ghozali, 2004:137). Artinya apabila instrumen yang digunakan dalam mencari data adalah valid maka data yang diperoleh untuk penelitian pasti juga valid.

\subsubsection{Uji Reliabilitas}

Uji reliabilitas adalah alat untuk mengukur item-item kuisioner yang merupakan indikator dari variabel. Tujuan dari menguji reliabilitas apabila digunakan adalah untuk memperolah data penelitian juga reliabel Berikut ini hasil pengujian uji reliabilitas dari variabel Kepemimpinan Transformasional, Kemampuan Manajerial, Karakteristik Pekerjaan, Motivasi Kerja dan Kinerja pegawai.:

Tabel 5.36

Hasil Uji Reliabilitas Instrumen

\begin{tabular}{|l|c|}
\hline \multicolumn{1}{|c|}{ Variable } & \multicolumn{1}{|c|}{$\begin{array}{c}\text { Alpha } \\
\text { Cronbanch }\end{array}$} \\
\hline $\begin{array}{l}\text { Kepemimpinan Transformasional } \\
(\mathrm{X} 1)\end{array}$ & 0.788 \\
\hline Kemampuan Manajerial (X2) & 0.776 \\
\hline Karakteristik Pekerjaan (X3) & 0.779 \\
\hline Motivasi (X4) & 0.774 \\
\hline Kinerja (Y) & 0,787 \\
\hline
\end{tabular}

Sumber : Lampiran spss

Pada Tabel 5.36 nilai Alpha Cronbanch masing-masing variabel lebih besar dari 0,60 dengan demikian item-item instrumen penelitian variabel Kepemimpinan Transformasional, Kemampuan Manajerial, Karakteristik Pekerjaan, Motivasi Kerja dan Kinerja pegawai sudah dinyatakan reliabel dan selanjutnya dapat digunakan dalam penelitian.

\section{Uji Hipotesis}

\section{Uji Kesesuaian Model (Uji F) / Simultan}

Uji $F$ digunakan untuk mengetahui tingkat signifikansi pengaruh variabel-variabel independen secara bersama-sama terhadap variabel dependen. Berdasarkan Tabel 5.41 didapatkan angka $F$ hitung 87,312 lebih besar dari $\mathrm{F}$ tabel sebesar 2,532 dengan Signifikansi0,000 < 0,05 , artinyaKepemimpinan

Transformasional, Kemampuan Manajerial, Karakteristik Pekerjaan dan Motivasi memiliki pengaruh simultan signifikan dan terhadap Kinerja pegawai sehingga model layak juga memenuhi goodness of fit.

Tabel 5.41

Uji F Hitung

\begin{tabular}{lc|r|r|r|r}
\multicolumn{7}{c}{ ANOVA $^{\text {a }}$} & & \\
& Sum of & & Mean & & \\
Square & D & Squar & & \\
Model & s & f & e & F & Sig. \\
\hline 1 Regressio & 40,023 & 4 & 10,00 & 87,31 &, 000 \\
n & & & 6 & 2 & b \\
\hline Residual & 7,105 & 62 &, 115 & & \\
\hline Total & 47,128 & 66 & & & \\
\hline
\end{tabular}

a. Dependent Variable: Y

b. Predictors: (Constant), X4, X2, X3, X1 Sumber : Print out spss

\section{Uji t}

Untuk mengetahui pengaruh signifikansi dari masing-masing variabel bebas secara parsial terhadap variabel terikat digunakan analisis uji t. 
Tabel 5.42

Koefisien Regresi Linier Berganda

\begin{tabular}{|c|c|c|c|c|c|}
\hline & & Coeffici & ents $^{a}$ & & \\
\hline & $\begin{array}{r}\text { Unstan } \\
\text { Coeffi }\end{array}$ & $\begin{array}{l}\text { dardiz } \\
\text { d } \\
\text { cients }\end{array}$ & $\begin{array}{l}\text { Standardiz } \\
\text { ed } \\
\text { Coefficien } \\
\text { ts }\end{array}$ & & \\
\hline Model & B & $\begin{array}{l}\text { Std. } \\
\text { Error }\end{array}$ & Beta & $\mathrm{t}$ & Sig \\
\hline $\begin{array}{l}1 \text { (Consta } \\
\text { nt) }\end{array}$ & ,146 & ,215 & & 678 & $\begin{array}{r}, 50 \\
0 \\
\end{array}$ \\
\hline $\mathrm{X} 1$ & ,348 & ,075, &, 352 & $\begin{array}{r}4,64 \\
3 \\
\end{array}$ & $\begin{array}{r}, 00 \\
0\end{array}$ \\
\hline $\mathrm{X} 2$ & ,187 & ,058, & 197, & $\begin{array}{r}3,22 \\
9\end{array}$ & $\begin{array}{r}, 00 \\
2\end{array}$ \\
\hline $\mathrm{X} 3$ & ,194 & 065, & 195 & $\begin{array}{r}2,98 \\
6 \\
\end{array}$ & $\begin{array}{r}, 00 \\
4 \\
\end{array}$ \\
\hline $\mathrm{X} 4$ & ,376 & 060 & ,392 & $\begin{array}{r}6,28 \\
1 \\
\end{array}$ & $\begin{array}{r}, 00 \\
0 \\
\end{array}$ \\
\hline
\end{tabular}

Sumber : Print out spss

a) Pengaruh secara parsial Kepemimpinan Transformasional terhadap Kinerja pegawai

Berdasarkan Tabel 5.42 dapat diketahui $\mathrm{t}$ hitung 4,643>t tabel $=$ 1,6698 dengan nilai signifikan 0,000 (lebih kecil dari 0,05), maka hipotesis diterima berarti variabel Kepemimpinan Transfomasional berpengaruh signifikan terhadap variabel Kinerja pegawai

b) Pengaruh secara parsial Kemampuan Manajerialterhadap Kinerja pegawai Berdasarkan Tabel 5.42 dapat diketahui $\mathrm{t}$ hitung 3,229> $\mathrm{t}$ tabel $=1,6698$ dengan nilai signifikan 0,000 (lebih kecil dari 0,05), maka hipotesis diterima berarti variabel Kemampuan Manajeria berpengaruh signifikan terhadap variabel Kinerja pegawai

c) Pengaruh secara parsial Karakteristik Pekerjaan terhadap Kinerja pegawai Berdasarkan Tabel 5.42 dapat diketahui $\mathrm{t}$ hitung 2,986> t tabel 1,6698 dengan nilai signifikan 0,000 (lebih kecil dari 0,05), maka hipotesis diterima berarti variabel Karakteritik Pekerjaan berpengaruh signifikan terhadap variabel Kinerja pegawai

d) Pengaruh secara parsial Motivasi Kerja terhadap Kinerja pegawai

Berdasarkan Tabel 5.42 dapat diketahui t hitung 2,986> t tabel 1,6698 dengan nilai signifikan 0,000 (lebih kecil dari 0,05), maka hipotesis diterima berarti variabel Motivasi berpengaruh signifikan terhadap variabel Kinerja pegawai

\section{Uji Beta / Dominan}

Pengujian yang dilakukan untuk mengetahui pengaruh dominan diantara variabel (independent) atau individu terhadap variabel terikat (dependent). Kaidah pengujiannya, jika nilai didapat coeficient beta standardized paling tinggi, maka variabel (independent) tersebut mempunyai pengaruh paling dominan terhadap variabel terikat (dependent).

Tabel 5.43

Coeficient beta standardized

\begin{tabular}{|l|c|c|}
\hline \multicolumn{1}{|c|}{ Variabel } & $\begin{array}{c}\text { Coeficie } \\
\text { nt beta } \\
\text { standard } \\
\text { ized }\end{array}$ & $\begin{array}{c}\text { Keteran } \\
\text { gan }\end{array}$ \\
\hline $\begin{array}{l}\text { Kepemimpinan } \\
\text { Transformasional (X1) }\end{array}$ & 0.352 & 2 \\
\hline $\begin{array}{l}\text { Kemampuan Manajerial } \\
\text { (X2) }\end{array}$ & 0.197 & 3 \\
\hline $\begin{array}{l}\text { Karakteristik Pekerjaan } \\
\text { (X3) }\end{array}$ & 0,195 & 4 \\
\hline Motivasi (X4) & 0,392 & 1 \\
\hline
\end{tabular}

Sumber : Print out spss

Berdasarkan Tabel 5.43 diperoleh nilai Coeficient beta standardized tertinggi 
95 Kindai, Vol 17, Nomor 1, Halaman 084 - 099

adalah pada variabel Motivasi dengan nilai Coeficient beta standardized sebesar 0,392 sehingga dapat diartikan bahwa Motivasi mempunyai pengaruh yang dominan terhadap Kinerja pegawai di Kantor Disporaparbud Kabupaten Barito Selatan.

\subsubsection{Uji Hipotesis}

1. Uji Kesesuaian Model (Uji F) / Simultan

Uji F digunakan untuk mengetahui tingkat signifikansi pengaruh variabel-variabel independen secara bersama-sama terhadap variabel dependen. Berdasarkan Tabel 5.41 didapatkan angka $\mathrm{F}$ hitung 87,312 lebih besar dari $\mathrm{F}$ tabel sebesar 2,532 dengan Signifikansi0,000 < 0,05 , artinyaKepemimpinan

Transformasional, Kemampuan Manajerial, Karakteristik Pekerjaan dan Motivasi memiliki pengaruh simultan signifikan dan terhadap Kinerja pegawai sehingga model layak juga memenuhi goodness of fit.

Tabel 5.41

Uji F Hitung

\begin{tabular}{lr|r|r|r|r}
\multicolumn{7}{c}{ ANOVA $^{\text {a }}$} & & \\
& Sum of & & Mean & & \\
Square & D & Squar & & \\
Model & s & f & e & F & Sig. \\
\hline 1 Regressio & 40,023 & 4 & 10,00 & 87,31 &, 000 \\
$\mathrm{n}$ & & & 6 & 2 & $\mathrm{~b}$ \\
\hline Residual & 7,105 & 62 &, 115 & & \\
\hline Total & 47,128 & 66 & & & \\
\hline
\end{tabular}

a. Dependent Variable: Y

b. Predictors: (Constant), X4, X2, X3, X1

Sumber : Print out spss

\section{Uji t}

Untuk mengetahui pengaruh signifikansi dari masing-masing variabel bebas secara parsial terhadap variabel terikat digunakan analisis uji t.

Tabel 5.42

Koefisien Regresi Linier Berganda

\begin{tabular}{|c|c|c|c|c|c|}
\hline & & Coeffic & ents $^{a}$ & & \\
\hline & $\begin{array}{r}\text { Unstan } \\
\text { Coeffi }\end{array}$ & $\begin{array}{l}\text { dardiz } \\
\text { d } \\
\text { cients }\end{array}$ & $\begin{array}{l}\text { Standardiz } \\
\text { ed } \\
\text { Coefficien } \\
\text { ts }\end{array}$ & & \\
\hline Model & $\mathrm{B}$ & $\begin{array}{l}\text { Std. } \\
\text { Error }\end{array}$ & Beta & $\mathrm{t}$ & Sig \\
\hline $\begin{array}{l}1 \text { (Consta } \\
\text { nt) }\end{array}$ & ,146 & ,215 & & ,678 & $\begin{array}{r}, 50 \\
0\end{array}$ \\
\hline $\mathrm{X} 1$ & ,348 & ,075 & ,352 & $\begin{array}{r}4,64 \\
3 \\
\end{array}$ & $\begin{array}{r}, 00 \\
0\end{array}$ \\
\hline $\mathrm{X} 2$ & ,187 & ,058 & 197 & $\begin{array}{r}3,22 \\
9 \\
\end{array}$ & $\begin{array}{r}, 00 \\
2 \\
\end{array}$ \\
\hline X3 & ,194 & ,065 & ,195 & $\begin{array}{r}2,98 \\
6 \\
\end{array}$ & $\begin{array}{r}, 00 \\
4\end{array}$ \\
\hline $\mathrm{X} 4$ & ,376 &, 060 & ,392 & $\begin{array}{r}6,28 \\
1\end{array}$ & $\begin{array}{r}, 00 \\
0\end{array}$ \\
\hline
\end{tabular}

Sumber : Print out spss

a) Pengaruh secara parsial Kepemimpinan Transformasional terhadap Kinerja pegawai

Berdasarkan Tabel 5.42 dapat diketahui $\mathrm{t}$ hitung 4,643> $\mathrm{t}$ tabel $=$ 1,6698 dengan nilai signifikan 0,000 (lebih kecil dari 0,05), maka hipotesis diterima berarti variabel Kepemimpinan Transfomasional berpengaruh signifikan terhadap variabel Kinerja pegawai

b) Pengaruh secara parsial Kemampuan Manajerialterhadap Kinerja pegawai

Berdasarkan Tabel 5.42 dapat diketahui $\mathrm{t}$ hitung 3,229> $\mathrm{t}$ tabel $=$ 1,6698 dengan nilai signifikan 
96 Kindai, Vol 17, Nomor 1, Halaman 084 - 099

0,000 (lebih kecil dari 0,05), maka hipotesis diterima berarti variabel Kemampuan Manajerial berpengaruh signifikan terhadap variabel Kinerja pegawai

c) Pengaruh secara parsial Karakteristik Pekerjaanterhadap Kinerja pegawai

Berdasarkan Tabel 5.42 dapat diketahui $\mathrm{t}$ hitung 2,986> $\mathrm{t}$ tabel 1,6698 dengan nilai signifikan 0,000 (lebih kecil dari 0,05), maka hipotesis diterima berarti variabel Karakteritik Pekerjaan berpengaruh signifikan terhadap variabel Kinerja pegawai

d) Pengaruh secara parsial Motivasi Kerja terhadap Kinerja pegawai

Berdasarkan Tabel 5.42 dapat diketahui $\mathrm{t}$ hitung 2,986> $\mathrm{t}$ tabel 1,6698 dengan nilai signifikan 0,000 (lebih kecil dari 0,05), maka hipotesis diterima berarti variabel Motivasi berpengaruh signifikan terhadap variabel Kinerja pegawai

\section{Uji Beta / Dominan}

Pengujian yang dilakukan untuk mengetahui pengaruh dominan diantara variabel (independent) atau individu terhadap variabel terikat (dependent). Kaidah pengujiannya, jika nilai didapat coeficient beta standardized paling tinggi, maka variabel (independent) tersebut mempunyai pengaruh paling dominan terhadap variabel terikat (dependent).

Tabel 5.43

Coeficient beta standardized

\begin{tabular}{|l|c|c|}
\hline \multicolumn{1}{|c|}{ Variabel } & $\begin{array}{c}\text { Coeficie } \\
\text { nt beta } \\
\text { standard } \\
\text { ized }\end{array}$ & $\begin{array}{c}\text { Keteran } \\
\text { gan }\end{array}$ \\
\hline $\begin{array}{l}\text { Kepemimpinan } \\
\text { Transformasional (X1) }\end{array}$ & 0.352 & 2 \\
\hline $\begin{array}{l}\text { Kemampuan Manajerial } \\
\text { (X2) }\end{array}$ & 0.197 & 3 \\
\hline Karakteristik Pekerjaan & 0,195 & 4 \\
\hline
\end{tabular}

\begin{tabular}{|l|l|l|}
\hline (X3) & & \\
\hline Motivasi (X4) & 0,392 & 1 \\
\hline
\end{tabular}

Sumber : Print out spss

Berdasarkan Tabel 5.43 diperoleh nilai Coeficient beta standardized tertinggi adalah pada variabel Motivasi dengan nilai Coeficient beta standardized sebesar 0,392 sehingga dapat diartikan bahwa Motivasi mempunyai pengaruh yang dominan terhadap Kinerja pegawai di Kantor Disporaparbud Kabupaten Barito Selatan.

\subsection{Pembahasan}

\subsubsection{Pengaruh Simultan}

Berdasarkan Uji Serentak / simultan (Uji F) tingkat signifikansi pengaruh variabelvariabel independen secara bersama-sama terhadap variabel dependen didapatkan angka $F$ hitung 87,312 lebih besar dari $\mathrm{F}$ tabel sebesar 2,532 dengan Signifikansi0,000 < 0,05, artinyaKepemimpinan

Transformasional, Kemampuan Manajerial, Karakteristik Pekerjaan dan Motivasi memiliki pengaruh simultan signifikan dan terhadap Kinerja pegawai.

Secara simultan

Kepemimpinan Transformasional, Kemampuan Manajerial, Karakteristik Pekerjaan dan Motivasi berkontribusi terhadap Kinerja Pegawai di Kantor Disporaparbud Kabupaten Barito Selatan, sebesar 0,849 atau 84,90\% , sedangkan sisanya sebesar $15,10 \%$ merupakan pengaruh yang datang dari faktor-faktor lain yang tidak diteliti dalam penelitian ini. 
Faktor lain misalnya, etos kerja, budaya organisasi, kompensasi, kepuasan kerja, loyalitas dan sebagainya. Temuan penelitian ini sejalan dengan pendapat Ander and Butzin (1982), yng mengajukan model kinerja : Future Perfomance $=$ Past Perfomannce + (Motivation $x$ Ability). Di dalamnya melibatkan dua komponen utama yakni Ability dan motivation. Formula ini menunjukkan bahwa kinerja merupakan hasil interaksi antara motivasi dan kemampuan. Tinggi ability-nya tetapi rendah motivasi-nya akan menghasilkan kinerja yang rendah, demikian sebaliknya, semakin tinggi ability dan motivasinya akan semakin tinggi kinerjany

\subsubsection{Pengaruh Parsial}

Untuk pengaruh secara Parsial masing - masing faktor Kepemimpinan Transformasional (X1), Kemampuan Manajerial (X2), Karakteristik Pekerjaan (X3), dan Motivasi Kerja (X4) Pegawai Dinas Pemuda, Olahraga, Pariwisata dan Kebudayaan Kabupaten Barito Selatan adalah :

a) Pengaruh secara parsial Kepemimpinan Transformasional terhadap Kinerja pegawai

Diketahui $\mathrm{t}$ hitung 4,643 $>\mathrm{t}$ tabel $=$ 1,6698 dengan nilai signifikan 0,000 (lebih kecil dari 0,05), maka hipotesis diterima berarti variabel Kepemimpinan

Transfomasional berpengaruh signifikan terhadap variabel Kinerja pegawai

b. Pengaruh secara parsial Kemampuan Manajerial terhadap Kinerja pegawai
Diketahui $\mathrm{t}$ hitung 3,229> $\mathrm{t}$ tabel $=$ 1,6698 dengan nilai signifikan 0,000 (lebih kecil dari 0,05), maka variabel Kemampuan Manajerial berpengaruh signifikan terhadap variabel Kinerja pegawai

c. Pengaruh secara parsial Karakteristik Pekerjaanterhadap Kinerja pegawai

Diketahui t hitung 2,986> t tabel 1,6698 dengan nilai signifikan 0,000 (lebih kecil dari 0,05), maka hipotesis diterima berarti variabel Karakteritik Pekerjaan berpengaruh signifikan terhadap variabel Kinerja pegawai

d. Pengaruh secara parsial Motivasi Kerja terhadap Kinerja pegawai

Diketahui t hitung 2,986> t tabel 1,6698 dengan nilai signifikan 0,000 (lebih kecil dari 0,05), maka variabel Motivasi berpengaruh signifikan terhadap variabel Kinerja pegawai.

\subsubsection{Pengaruh Dominan}

Sesuai dengan hipotesis yang diajukan bahwa Motivasi berpengaruh dominan terhadap Kinerja pegawai, hal ini telah terbukti dengan nilai beta sebesarr 0,392 paling besar nilainya dibandingkan dengan nilai beta variable lainnya.

\section{PENUTUP}

\subsection{Kesimpulan}

Dari analisis hasil penelitian dan pembahasan yang telah dilakukan pada bab sebelumnya, maka dihasilkan beberapa kesimpulan sebagai berikut : 
1. Motivasi Kerja berpengaruh secara dominan terhadap kinerja pegawai Kantor Disporaparbud.

2. Kepemimpinan Transformasional (X1), Kemampuan Manajerial (X2), Karakteristik Pekerjaan (X3) dan Motivasi Kerja (X4 memiliki kontribusi positif dan signifikan terhadap Kinerja pegawai di Kantor Disporaparbud Kabupaten Barito Selatan, sedangkan sisanya dipengaruhi variable lain yang tidak masuk dalam peneitian ini.

3. Kepemimpinan Transformasional (X1) yang diukur oleh Kinerja pegawai (Y) memiliki kontribusi yang positif dan signifikan terhadap tinggi rendahnya Kinerja pegawai Kantor Disporaparbud Kabupaten Barito Selatan.

4. Kemampual Manajerial (X2) yang diukur oleh Kinerja pegawai (Y) memiliki kontribusi yang positif dan signifikan terhadap tinggi rendahnya Kinerja pegawai Kantor Disporaparbud.

5. Karakteristik Pekerjaan (X3) yang diukur oleh Kinerja pegawai (Y) memiliki kontribusi yang positif dan signifikan terhadap tinggi rendahnya Kinerja pegawai Kantor Disporaparbud.

6. Motivasi (X4) yang diukur oleh Kinerja pegawai (Y) memiliki kontribusi yang positif dan signifikan terhadap tinggi rendahnya Kinerja pegawai Kantor Disporaparbud.

\subsection{Saran}

Berdasarkan hasil penelitian dan pembahasan serta kesimpulan yang telah dijelaskan sebelumnya, peneliti memberikan saran-saran sebagai berikut :
1. Agar pihak Disporarbud kira nya memetakan kemampuan sumber daya manusia tiap bidang yang dimiliki nya sehingga kegiatan kegiatan bidang dapat di kerjakan tiap bidang tanpa bantuan dari bidang lain.

2. Untuk meningkat kan sumber daya manusia tiap bidang Disporaparbud dapat mengikutsertakan pegawai - pegawainya untuk mengikuti diklat atau pelatihan peningkatan sumber daya manusia yang pendanaan nya di alokasikan dinas.

3. Secara umum hasil penelitian ini menunjukkan dukungan bagi teori yang sudah ada selama ini yang dipergunakan sebagai landasan penelitian, oleh karenanya bagi para peneliti berikutnya disarankan perlunya untuk meninjau dan memperluas tentang variabel yang telah dipergunakan dalam penelitian ini dengan variabel yang baru.

\section{DAFTAR PUSTAKA}

Luthans, Fred, 2006, Perilaku Organisasi, Edisi Sepuluh, PT. Andi : Yogyakarta. Northouse, Peter G. 2013:175 \& 185. Kepemimpinan. Teori dan Praktik. Edisi ke-6. ISBN: 978-1-4522-0340-9. Jakarta. Indeks

Madura, Jeff, 2001. Pengantar Bisnis. Terjemahan. Jakarta : Penerbit Salemba Empat.

Handoko, T. Hani, 2006, Manajemen Personalia dan Sumber Daya Manusia, Edisi Kedua, Cetakan Keempatbelas, BPFE, Yogyakarta.

Handoko, H T, 1990, Manajemen Personalia dan Sumber Daya Manusia, Edisi Pertama, Yogyakarta, BPFE.

Mangkuprawira. Syafri, 2007. Manajemen Sumber Daya Manusia Stratejik, Cetakan Kedua, Ghalia Indonesia, Jakarta. 
99 Kindai, Vol 17, Nomor 1, Halaman 084 - 099

Mangkunegara, Anwar P. 2005, Manajemen Kontroversi, Aplikasi, Edisi kedelapan Sumber Daya Manusia Perusahaan, Terjemahan, PT. Prenhallindo, Jakarta. Cetakan Ketiga, PT. Remaja Rosdakarya Offset, Bandung

Prawirosentono, Suyadi, 2005, Kebijakan Kinerja Karyawan, BPFE, Yogyakarta

Robbins, S, 2006, Perilaku Organisasi, Edisi Kelima, Penerbit Erlangga, Jakarta

Robbins, S, 2005, Prinsip-Prinsip Perilaku Organization, Edisi Kelima, Penerbit Erlangga, Jakarta.Robbins, Stephen. P, 2001, Perilaku Organisasi : Konsep, Organizational Behavior. New York. John Willet \& Sons, Inc. 